\title{
Analyses of Mentoring Expectations, Activities, and Support in Canadian Academic Libraries
}

\section{Marni R. Harrington and Elizabeth Marshall}

\begin{abstract}
Mentoring expectations, activities, and support in Canadian college and university libraries were investigated by surveying 332 recent MLIS graduates, practicing academic librarians, and library administrators. Findings indicate that the presence of a mentoring program will help attract new librarians, retain them, and aid in restructuring efforts that are currently facing many academic libraries. Preferred mentoring activities include those belonging to psychosocial support, career guidance, and role modeling themes. Other results find that librarians who were mentored as new librarians, have more than 10 years of experience, and work in large academic institutions are significantly more likely to mentor others. Although currently not well-supported by academic administrators, this research shows that mentoring programs could be sustainable. Mentoring improves the professional experience for librarians who are more satisfied and engaged with their careers, which in turn benefits the organization with less turnover. Practical information from this research will guide academic library practitioners in current mentoring relationships, and library leaders can extrapolate results to support planning and implementation of mentoring programs. Implications for LIS education are also discussed.
\end{abstract}

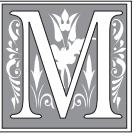

entoring is an activity, whether formal or informal, that is frequently associated with many professional occupations, but what does it look like in Canadian academic libraries? Informal mentoring is an independent activity initiated by a mentor, the person who acts as a guide, adviser, and provider of support, or by a mentee, the person who receives guidance, advice, and support. In contrast, formal mentoring relationships are often those organized by administration with the expectation that both mentees and mentors will participate. The present research investigates how both formal and informal mentoring is operationalized in Canadian academic libraries, as well as specific characteristics of, and attitudes toward, mentoring. The present study focuses on Canadian colleges and universities, although the implications of this research may apply more broadly.

Marni R. Harrington is an Associate Librarian in the Faculty of Information $\mathcal{E}$ Media Studies, and Elizabeth Marshall is Director of the C.B. "Bud" Johnston Library, Western Libraries, both at The University of Western Ontario; e-mail: mharring@uwo.ca, emarsha3@uwo.ca. Research for this article was partially funded by a grant from the Canadian Library Association, Canadian Association of College and University Libraries Division. (C2014 Marni R. Harrington and Elizabeth Marshall, Attribution-NonCommercial (http://creativecommons.org/licenses/by-nc/3.0/) CC BY-NC 
Mentoring research in academic libraries includes numerous case studies, and the literature contains many practical guides, but there is a lack of research that explores mentoring programs, opportunities, and expectations in Canadian college and university libraries. Including college with university libraries is appealing because, although both are academic institutions, there is little research about college libraries or librarians around the globe, or in Canada specifically. ${ }^{1}$ A Canadian perspective on mentoring is an important extension of the 8Rs Study: The Future of Human Resources in Canadian Libraries from 2005, which, among other key elements, stresses the importance of recruitment, retention, and restructuring. ${ }^{2}$ In this current study, recruitment refers to an institution's ability to attract qualified candidates, retention refers to keeping the librarian in the institution or position, and restructuring is the way in which an institution might reorganize personnel to address staff shortages and a lack of financial resources. The relationship between mentoring and these 3Rs is further investigated by addressing who is mentoring in Canadian college and university libraries, whether academic librarians expect to be mentored, the perceived importance of possible mentoring activities, and the degree to which mentoring is supported by library administration. This is the first study to investigate these issues in Canadian academic libraries. The study objectives are explored through surveys of new graduates from an ALA-accredited master's of library and information science (MLIS) program, professional librarians (those holding a MLIS or equivalent), and library administrators (university librarians, deans, or administrative equivalents).

\section{Literature Review}

Much has been written on organizational mentoring as a tool for recruitment, retention, and restructuring. The focus here is on the benefits of mentoring, mentoring in academic libraries, and mentoring in Canadian libraries. Within the framework of academic libraries, mentoring is advantageous for new librarians entering the work force, as well as practicing librarians at different career stages, including those of leadership. The difference between formal and informal mentoring, and many other mentoring approaches, are acknowledged but not specifically addressed in this literature review (such as peer-to-peer; group; virtual). The current research does not favor one form of mentoring over another; rather, it addresses the underlying support that may be attributed to successful programs regardless of the form.

\section{Benefits of Mentoring}

Mentoring offers established and proven best practices to enhance organizational and individual learning. ${ }^{3}$ Mentoring programs have proven to be one of the most significant factors contributing to an individual's career success, including promotion and retention. ${ }^{4}$ Benefits reported in Eby's study of formal mentoring included personal gratification, learning, and developing relationships. ${ }^{5}$

Mentoring relationships are beneficial for all who participate. When comparing professionals who were or were not mentored, Allen found that mentored professionals, or mentees, reported higher compensation, more promotions, and increased satisfaction with their career. ${ }^{6}$ These same professionals were also more likely to believe that they would advance in their careers. The act of mentoring was an indicator of career success for the mentors as well. In other work, Allen also found that professionals who mentored reported a higher level of satisfaction, higher current salaries, and more promotions than colleagues without mentoring experience. ${ }^{7}$ For new employees (the mentees), mentoring supports orientation and socialization, helps in fostering and adopting organizational goals and values, helps to shape positive attitudes, and can be used to demonstrate effective role modeling. ${ }^{8}$ Others have found that participation in future mentoring is based 
on past experiences; and for mentoring to be successful, and hence a good experience, it must be managed to determine what makes it effective and satisfying. ${ }^{9}$

From an organizational perspective, Mathews found that the presence of mentoring programs in higher education is also beneficial in terms of making professionals feel more valued. ${ }^{10}$ This feeling of value is then translated into an increased commitment by the professionals and may reduce turnover in the organization. Mentoring also plays a role in transmitting and perpetuating the organization's culture; and, when the culture of an organization is understood, individuals are more likely to succeed.

Finally, several articles cite the benefits for women in academia who participate in mentoring opportunities or program. ${ }^{11}$ Over fifteen years ago, Kirkland surveyed 135 female directors of academic libraries and found mentoring to be one of the most highly ranked variables for career success. ${ }^{12}$ These findings are important for library workers in Canadian academic institutions because females traditionally account for a majority $(70 \%-80 \%)$ of the workforce. ${ }^{13}$

\section{Mentoring in Academic Libraries}

Osif reviewed a variety of mentoring programs within academic libraries and beyond to itemize program similarities and differences. ${ }^{14}$ The differences outnumbered the similarities considerably. From the length of the mentoring program to what the mentoring participants were called, a "magic mentoring program that is appropriate for all libraries" was not evident. However, the positive outcomes associated with mentoring were evident; because of this, Osif urges the development of mentoring cultures within libraries. Recently, Shupe and Pung compiled a current and excellent review on mentoring as an important factor in librarian development. ${ }^{15}$ Culpepper's work also reviews the literature on mentoring in academic libraries and highlights the benefits for both mentors and mentees framed around career guidance. She discusses the benefits of mentoring new librarians for successful integration into the institutional culture and the benefits for more experienced librarians when mentoring is available for support in leadership roles. ${ }^{16}$

Most of the literature on mentoring in academic libraries is based on case studies or reviews concerning "how we did it at our institution or library." 17 Often, a case study focuses on a particular problem or need within a particular library. Specific problems include retaining librarians, or supporting librarians in the tenure and promotion process. Retention rates for minority librarians have also been documented to be problematic because of issues of lower pay, lack of advancement, and being overlooked for important committees and projects. ${ }^{18}$ Olivas and Ma discovered that, on average, minority librarians who did not have a mentor, or failed to keep in contact with a mentor, rated job satisfaction quite low. ${ }^{19}$ In addition, many planned on leaving librarianship as a profession within the next five years. Conversely, minority librarians who had been mentored perceived many benefits, including greater job satisfaction, and improved promotion possibilities within the organization.

\section{Mentoring and New Librarians}

Mentoring can play a role in the recruitment of the most qualified library candidates. The importance of a mentoring plan for new hires was discussed in a 2002 Association of College and Research Libraries (ACRL) Task Force investigation. ${ }^{20}$ They found that newer professionals may be more influenced by not just salary, job duties, and professional development, but also mentoring. It may be the case that new librarians' mentoring expectations are growing over time. Black and Leysen found that informal mentoring was important to 75 percent of the 122 new librarians working at the ARL libraries they surveyed and state that these mentoring programs are critical for the 
transition from graduate school to new a career. ${ }^{21}$ Oud's recent study of newly employed librarians at academic libraries in Canada found significant differences between expectations prior to starting their job, and their actual work experiences. ${ }^{22}$ Most differences were about the organizational culture. To adjust to the culture of a new organization, Oud suggests using formal or informal training programs, and the assignment of a mentor or buddy as someone who can provide feedback, information, and support without judgment. Farmer, Stockham and Trussell commented on the importance of a mentoring program to "meet the needs of new employees and effectively impart the information and advice in a coordinated, ongoing process." ${ }^{23}$

It is understood that the successful transition from a library school graduate program to a practicing academic librarian requires a complex combination of skills. ${ }^{24}$ Knowing that a mentoring program is available for a new librarian may be appealing. As academic libraries try to attract the best graduates, highlighting mentoring programs to the applicants could only be beneficial, particularly when the literature demonstrates that this is what they expect.

\section{Mentoring and Retention}

Recruitment and retention of qualified academic librarians is a concern in many academic libraries. Successful recruitment and retention techniques were investigated at different stages of librarians' careers at 69 member libraries of the Association of Research Libraries (ARL) ${ }^{25}$ The survey asked about a list of factors that seemed to have the most positive impact on retention of librarians at different stages of their careers. Although the most important factors for newer librarians were support for professional development (68\%), position responsibilities and salary $(46 \%)$, and benefits $(42 \%)$, mentoring within the library (35\%) was also considered to be an important retention factor. In contrast, mid-career, late-career, and management-level librarians did not see mentoring as advantageous, with response rates of 13 percent, 2 percent, and 2 percent respectively. Although formal mentoring programs in libraries are widely recommended in the literature as a tool for increasing retention, Strothmann and Ohler recently found in their large survey of ARL librarians that mentoring was available to only 22 percent of their academic librarian respondents. ${ }^{26}$

A variety of mentoring programs have been created to help academic librarians meet the promotion and tenure requirements and ultimately to aid in the retention of those librarians. For example, the goals and principles of the mentoring program at Louisiana State University were formally designed to assist new librarians in meeting tenure. ${ }^{27}$ This experiment was evaluated after one year to assess whether the program was meeting its goals. It then was modified as necessary to increase the probability of continued success. A somewhat different approach was taken at Oakland University, where an informal mentoring program encouraged relationships among untenured librarians. ${ }^{28}$ The untenured librarians meet to offer support and advice, without evaluation. When a librarian obtains tenure, he or she is dismissed from the group. Finally, a formal team mentoring model was reported at California State University, Long Beach. ${ }^{29}$ This interesting combination of mentoring, coaching, and training also includes a broader network of support for mentors and mentees, and the responsibility does not fall to one person but, rather, a group. In this team approach, mentoring is a mandatory service activity in which three senior librarians offer support, guidance, and training to new librarians.

\section{Mentoring and Leadership}

Recently, Nixon has written about mentoring as a successful strategy for succession planning and restructuring. ${ }^{30}$ Due to retirements, primarily in leadership positions, she offers a "grow your own leaders" ideology that includes a mentoring program to 
prepare leaders for future opportunities. For mid-career librarians, mentoring is often associated with leadership roles or the advancement to different positions in the organization. ${ }^{31}$ It should be noted, however, that not all librarians have a desire to advance to roles of managers or administrators; instead, they may be motivated by leadership opportunities for project planning and special assignments. ${ }^{32}$ Regardless, Hicks outlines problems that may arise when mentoring is used for developing. ${ }^{33}$ Some of these risks include inappropriate mentors and the problems dividing the role when your mentor is also your supervisor. ${ }^{34}$ Hicks stresses that mentoring must be used critically for it to be an effective tool and positively affect librarianship.

Regardless of whether the library mentoring was a formal or an informal program, or involved single or multiple mentors, when used critically, the benefits offset the problems for the participants and the organization. Benefits of mentoring are documented in terms of orientation to a new organization,,$^{35}$ as well as developing and enhancing careers. ${ }^{36}$ Specific benefits such as help with organizing and submitting a file for tenure and promotion are also significant. ${ }^{37}$

\section{Mentoring in Canadian Libraries}

The mentoring literature focuses mainly on the American experience, ${ }^{38}$ with some examples from Australia, ${ }^{39}$ however, there is a lack of literature discussing the mentoring experiences of librarians in Canadian academic libraries. Law detailed mentoring programs at the University of Alberta in which three models of mentoring were developed to test whether there was an ideal model for their library. ${ }^{40}$ She concluded that there was not one perfect model, but several aspects of the three pilot projects had successful elements. The successful elements involved one-on-one collegial relationships, a focus on understanding the academic community, and a shared understanding about the parameters of the mentoring relationship including time, outcomes, and confidentiality. Oud's research, as mentioned previously, focused on new academic librarians at Canadian universities and addressed not only mentoring, but training and orientation programs as well. Although Oud's study provides a valuable perspective on new librarians, it did not include a representation of librarians from a variety of career stages or those in college libraries, which are also objectives of the present research.

Finally, The Future of Human Resources in Canadian Libraries examined recruitment, retention, remuneration, reaccreditation, repatriation, rejuvenation, retirement, and restructuring in academic and public libraries across Canada. ${ }^{41}$ Restructuring and change in academic libraries is a constant. Easy access to organizational knowledge is fundamental in dynamic environments, such as libraries, that demand continuous adaptation. ${ }^{42}$ However, the 8 Rs study reported that only 10 percent of Canadian academic libraries have a succession plan to account for change in recruitment, development, and replacement of staff. Mentoring, in the current research, is also viewed as a potential and effective tool to support succession planning and restructuring. As such, mentoring participants act as facilitators to knowledge that needs to be passed on in times of change.

In summary, successful mentoring initiatives reveal positive outcomes for mentors, mentees, and the organization. Research and case studies have demonstrated a role for mentoring to solve issues within academic libraries such as recruitment, retention, and restructuring. The current research investigates these elements with respect to Canadian academic librarians.

\section{Research Questions}

The broad question concerning the current state of mentoring in Canadian academic libraries is addressed by focusing on the following research questions:

1. Who is mentoring in college and university libraries? 
2. Do academic librarians expect to be mentored?

3. What are the perceived important activities in a mentoring relationship?

4. Is mentoring supported by academic administration?

\section{Methodology}

Stratified, purposeful sampling was used to highlight mentoring in academic libraries. An online survey consisted of 15-30 questions depending on the respondent group (new MLIS graduates, practicing librarians, and administrators). The majority of the questions were close-ended, with ordered choices designed to capture expectations and experiences with library workplace mentoring, and the availability of mentoring opportunities. Open-ended qualitative questions provided an opportunity for respondents to detail mentoring knowledge and experience not captured in other questions. Limited demographic data were also collected. The abbreviated surveys are presented in Appendix A.

\section{Participants}

Three distinct groups were targeted. One group consisted of recent MLIS graduates who are interested in academic library careers. A second group consisted of individuals who are currently employed as professional librarians at college or university libraries. Finally, one library director, dean, or head of libraries per institution was contacted for the third group.

Recent MLIS graduate students from a large Canadian library and information science program made up the first group of participants. It was justified that including only recent graduates from one graduate program was adequate due to the nature of this particular program. Specifically, the master's program may be completed in twelve months, and there is a co-op component that attracts hundreds of students per year from across the country. All practicing librarians, as well as directors, deans, or heads of Canadian academic libraries, were invited to participate.

\section{Procedure}

An invitation to participate was sent out in December 2010, with a reminder in January 2011. A second group of MLIS students who graduated in spring 2011 was sent an invitation to participate in May 2011. A \$50 gift certificate to a Canadian bookseller was used as a participation incentive-one for the student group and one for the librarian group.

\section{Results and Discussion}

Twenty-three MLIS graduates, 292 academic librarians (43 college and 245 university librarians), and 21 academic library administrators ( 7 college and 14 university) completed the survey. The response rates were 17 percent for college librarians and 21 percent for university librarians, which are comparable to the response rates of 13 percent for college administrators and 18 percent for university administrators. Response rates for MLIS graduates could not be calculated, because it is unknown how many recent graduates were interested in academic librarianship but did not agree to participate. Note that sample sizes differ across the groups, due to differences in the populations of Canadian university and college academic librarians and administrators.

Survey data were analyzed using SPSS.

\section{Demographic Information}

Provincial, personal, and institutional demographics show Canada-wide participation. As presented in table 1, a cross-Canada representation was achieved. It can be noted that the number of participants in this study mirrors the distribution of universities 


\begin{tabular}{|c|c|c|c|c|}
\hline \multicolumn{5}{|c|}{$\begin{array}{c}\text { TABLE } 1 \\
\text { Canadian Representation }\end{array}$} \\
\hline Province & $\begin{array}{c}\text { College } \\
\text { Librarians }\end{array}$ & $\begin{array}{l}\text { University } \\
\text { Librarians }\end{array}$ & $\begin{array}{c}\text { College } \\
\text { Administrators }\end{array}$ & $\begin{array}{c}\text { University } \\
\text { Administrators }\end{array}$ \\
\hline British Columbia & 11 & 37 & 4 & 1 \\
\hline Alberta & 7 & 41 & 1 & 1 \\
\hline Manitoba & 2 & 10 & & 1 \\
\hline Saskatchewan & & 13 & & 1 \\
\hline Ontario & 15 & 97 & 1 & 6 \\
\hline Quebec & 1 & 15 & & 1 \\
\hline New Brunswick & & 5 & & \\
\hline Nova Scotia & 3 & 12 & & 2 \\
\hline $\begin{array}{l}\text { Newfoundland and } \\
\text { Labrador }\end{array}$ & 3 & 3 & & 1 \\
\hline Prince Edward Island & 1 & & & \\
\hline Northwest Territories & & & 1 & \\
\hline
\end{tabular}

and colleges throughout Canada. For example, Ontario has the most college $(n=15)$ and university $(\mathrm{n}=97)$ librarian respondents, reflecting the fact that the province of Ontario has the most colleges and universities. There were no respondents from Yukon or Nunavut, but there is also only a small number of postsecondary institutions in these regions. Specifically, there is only one recognized postsecondary institution in each: Yukon College and Nunavut Arctic College.

Respondents' ages follow an expected trajectory (see figure 1). Recent graduates are the youngest respondents ( $n=14$ in 20-30 years old), whereas the majority of the administration groups' respondents are over 51 years $(n=16)$. The academic librarians

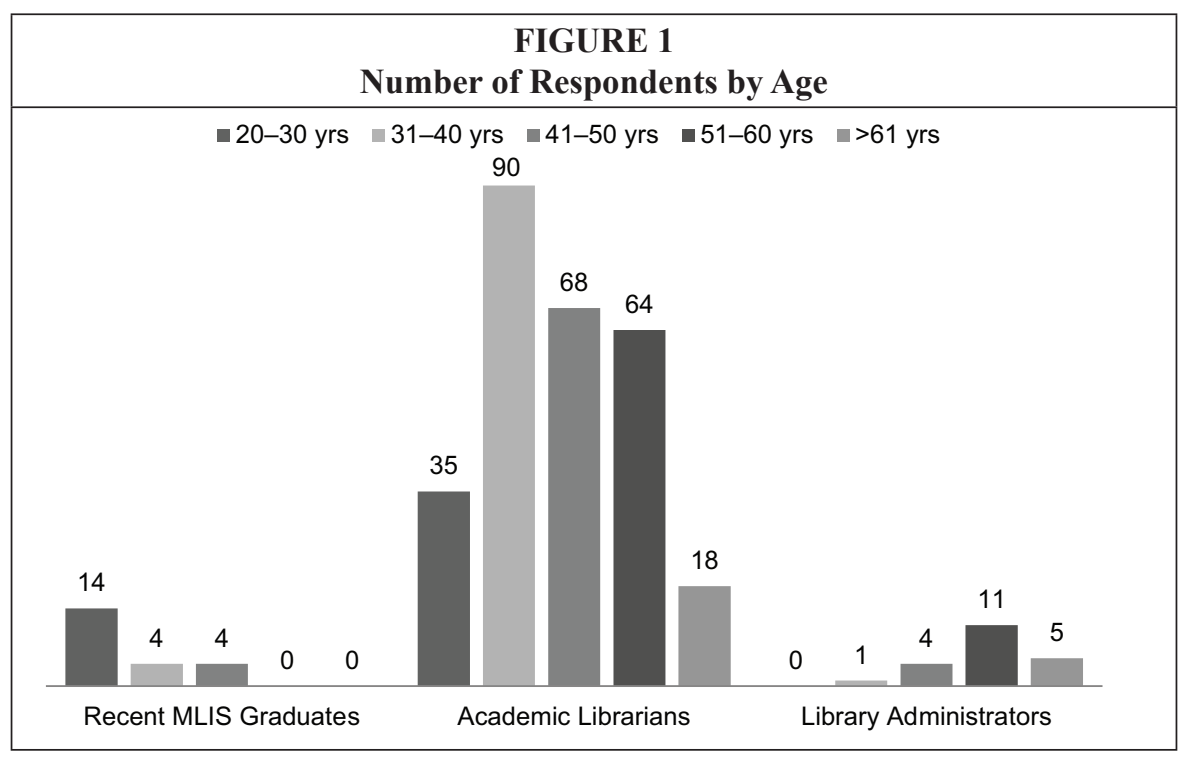


are represented across all age ranges, with 31-40 years being the most represented. Almost half (45\%) of the librarian respondents across the colleges and universities are younger than 40 .

The number of years that the respondents have worked in an academic library varies considerably (see table 2). Approximately one third of the college and university librarian respondents have worked in an academic library for five years or less, which may indicate that newer librarians were more likely to participate in this type of research survey due to the personal relevance of mentoring, or general interest in supporting colleagues in research endeavors. In the administration group, most respondents have been working in an academic library for more than 11 years. Furthermore, it is not surprising that more than half of the university administrators have more than 21 years of experience. Also interesting to note here is that all of the library administrators have an MLIS or equivalent.

TABLE 2

How Many Years Have You Worked in an Academic Library?

\begin{tabular}{|c|c|c|c|c|}
\hline $\begin{array}{l}\text { Years as Academic } \\
\text { Librarian }\end{array}$ & $\begin{array}{c}\text { College } \\
\text { Librarians }\end{array}$ & $\begin{array}{c}\text { University } \\
\text { Librarians }\end{array}$ & $\begin{array}{c}\text { College } \\
\text { Administrators }\end{array}$ & $\begin{array}{c}\text { University } \\
\text { Administrators }\end{array}$ \\
\hline $0-5$ & 16 & 80 & 1 & 0 \\
\hline $6-10$ & 11 & 52 & 0 & 2 \\
\hline $11-20$ & 10 & 53 & 3 & 4 \\
\hline$>21$ & 5 & 53 & 3 & 8 \\
\hline
\end{tabular}

Interesting results for the recent graduates include their pre-MLIS degrees and library mentoring experiences. Most of the recent graduates entered their MLIS program with a BA $(66 \%)$, while 40 percent also have other graduate degrees, primarily in arts and social sciences. More than half stated that they had participated in, or had the opportunity to participate in, mentoring activities. These included some type of mentoring during co-operative work placement or work study, participation in job shadowing, or student mentoring activities.

Because of the anonymity of the study, responses cannot be grouped by, or identified with, a particular institution; rather, they portray characteristics of the respondent groups. The tables below highlight the size of the campus at which respondents work by listing the number of librarians employed at the institution (see table 3) and student enrollment (see table 4). College librarians and administrators represent small and medium-sized institutions. University librarians and administrators represent a wider range of institutional sizes. In addition, many of the respondents work at an institution

TABLE 3

How Many Professional Librarians are Employed at Your Institution?

\begin{tabular}{|l|c|c|c|c|}
\hline $\begin{array}{l}\text { Number of } \\
\text { Professional } \\
\text { Librarians }\end{array}$ & $\begin{array}{c}\text { College } \\
\text { Librarians } \\
(\mathbf{n}=\mathbf{3 9})\end{array}$ & $\begin{array}{c}\text { University } \\
\text { Librarians } \\
(\mathbf{n}=\mathbf{1 9 3})\end{array}$ & $\begin{array}{c}\text { College } \\
\text { Administrators } \\
(\mathbf{n}=\mathbf{7})\end{array}$ & $\begin{array}{c}\text { University } \\
\text { Administrators } \\
(\mathbf{n}=\mathbf{1 4})\end{array}$ \\
\hline $1-5$ (small) & $39 \%$ & $3 \%$ & $57 \%$ & $7 \%$ \\
\hline $6-20$ (medium) & $61 \%$ & $29 \%$ & $43 \%$ & $35 \%$ \\
\hline $21-50$ (large) & & $42 \%$ & & $42 \%$ \\
\hline$>50$ (very large) & & $26 \%$ & & $14 \%$ \\
\hline
\end{tabular}




\begin{tabular}{|l|c|c|c|c|}
\hline \multicolumn{5}{|c|}{ TABLE 4 } \\
\hline $\begin{array}{l}\text { Humber of } \\
\text { Students }\end{array}$ & $\begin{array}{c}\text { College } \\
\text { Librarians } \\
(\mathbf{n = 4 1 )}\end{array}$ & $\begin{array}{c}\text { University } \\
\text { Librarians } \\
(\mathbf{n = 2 0 2})\end{array}$ & $\begin{array}{c}\text { College } \\
\text { Administrators } \\
(\mathbf{n}=\mathbf{7})\end{array}$ & $\begin{array}{c}\text { University } \\
\text { Administrators } \\
(\mathbf{n}=\mathbf{1 4})\end{array}$ \\
\hline Less than 5,000 & $26 \%$ & $11 \%$ & $57 \%$ & $21 \%$ \\
\hline 5,000 to 10,000 & $39 \%$ & $12 \%$ & $43 \%$ & $15 \%$ \\
\hline 10,000 to 20,000 & $19 \%$ & $19 \%$ & & $21 \%$ \\
\hline More than 20,000 & $16 \%$ & $57 \%$ & & $43 \%$ \\
\hline
\end{tabular}

with more than one library on campus ( $60 \%$ of the college librarians; $86 \%$ of college administrators; $77 \%$ of the university librarians; $71 \%$ of university administrators).

\section{Mentoring Practices and Expectations}

Mentoring practices and expectations vary among the groups. For example, 25 percent of college librarians, 34 percent of university librarians, 14 percent of college administrators, and 36 percent of university administrators indicated that they had received some type of mentoring when they began their career. Mentoring of some kind is occurring in the libraries of 42 percent of the college librarian respondents and 29 percent of college administrators. In contrast, the libraries of 56 percent of university librarian respondents and 31 percent of university administrators had some type of mentoring program. This is broken down further in figure 2. Formal mentoring represents only 14 percent and 15 percent of the programs reported by the college and university librarians. These figures are somewhat lower than the 22 percent reported for ARL librarians. ${ }^{43}$

The characteristics of mentors were investigated to determine who is participating in mentoring programs within these libraries. Significant relationships exist between the following pairs of variables: having a mentoring program and student population, being a mentor and number of years as a librarian, and being a mentor and having been mentored in the past.

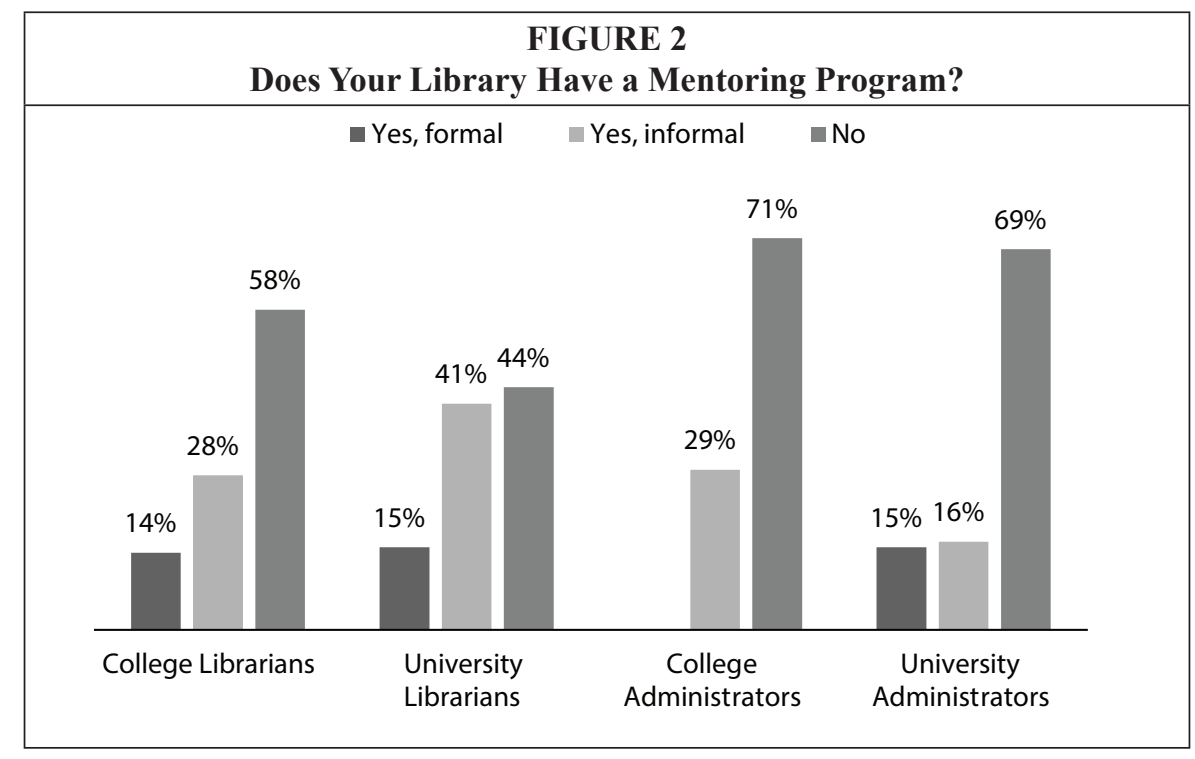


Table 5 shows a significant relationship between mentoring and student population, $\chi^{2}(3)=12.58, p<.007$. The larger the institution, as measured by student population, the more likely it is that the library will have a mentoring program. Understandably, more opportunities for formal and informal mentoring may be available in larger institutions because these institutions have a greater number of librarians who are potentially available to participate. Furthermore, because it is likely that a large institution has more opportunities with new librarians in the system, mentoring may be viewed as more important.

TABLE 5

Relationship Between Mentoring and Student Population

\begin{tabular}{|l|c|c|c|}
\hline \multirow{2}{*}{ Number of Students } & \multicolumn{2}{|c|}{ We Have a Mentoring Program } & \multirow{2}{*}{$\%$ Yes } \\
\cline { 2 - 3 } & Yes & No & $31 \%$ \\
\hline$<5,000$ & 12 & 27 & $49 \%$ \\
\hline $5-10,000$ & 22 & 23 & $62 \%$ \\
\hline $10-20,000$ & 32 & 20 & $61 \%$ \\
\hline$>20,000$ & 86 & 56 & \\
\hline
\end{tabular}

Table 6 shows a significant relationship between librarians who mentor and the number of years that they have been academic librarians, $\chi^{2}(3)=23.51, p<.001$. The longer a respondent has been a librarian, the more likely it is that he or she has been a mentor. More specifically, after ten years as an academic librarian, the likelihood of mentoring doubles. Those with fewer than 10 years were less likely (20\%) to have mentored. While it makes sense that more experienced librarians are mentors, the low proportion of mentors among librarians with six to ten years of service is surprising.

\begin{tabular}{|l|c|c|c|}
\hline \multicolumn{4}{|c|}{ TABLE 6 } \\
\multicolumn{2}{|c|}{ Librarians: Is Number of Years as Librarian Related To Mentoring? } \\
\hline $\begin{array}{l}\text { Number of Years as } \\
\text { Academic Librarian }\end{array}$ & \multicolumn{2}{|c|}{ I Am a Mentor } \\
\cline { 2 - 4 } & Yes & No & \% Yes \\
\hline 0 to 5 & 13 & 82 & $14 \%$ \\
\hline 6 to 10 & 12 & 52 & $19 \%$ \\
\hline 11 to 20 & 27 & 37 & $42 \%$ \\
\hline$>21$ & 23 & 34 & $40 \%$ \\
\hline
\end{tabular}

Table 7 shows a significant relationship between having been mentored as a new librarian and mentoring others, $\chi^{2}(1)=5.96, p<.02$. This suggests that librarians who were mentored are more likely to be a mentor. Hence, the sustainability of a mentoring program derives from the support it receives: if it is supported and there is participation, it will continue. This is similar to Olivas and Ma's findings that minority librarians who had been mentored were the ones who now planned to mentor new librarians because of the benefits they had experienced as a mentee. ${ }^{44}$

Surprisingly, respondents who are currently librarians had very low mentoring expectations when they were new librarians. Of the respondents who did not have a mentor, only 28 percent of college and 16 percent of university librarians expected 


\begin{tabular}{|c|c|c|c|}
\hline \multicolumn{4}{|c|}{$\begin{array}{c}\text { TABLE } 7 \\
\text { Librarians: Is There a Relationship Between Being Mentored and } \\
\text { Being a Mentor? }\end{array}$} \\
\hline \multirow{2}{*}{$\begin{array}{l}\text { I Was Mentored as a New } \\
\text { Librarian }\end{array}$} & \multicolumn{2}{|c|}{ I Am a Mentor } & \multirow[b]{2}{*}{$\%$ Yes } \\
\hline & Yes & No & \\
\hline Yes & 34 & 60 & $36 \%$ \\
\hline No & 42 & 145 & $22 \%$ \\
\hline
\end{tabular}

to have a mentoring relationship when they began their library careers. None of the college or university administrators reported having this expectation. This is in stark contrast to 83 percent of the recent MLIS graduates who agreed with this statement: "Thinking about my future (or new) employment in an academic library, I expect mentoring to be available." Clearly, expectations have changed, and new graduates expect formal or informal mentoring to be offered when they begin their career in an academic library. Hicks and Black agree, stating that mentoring programs are critical for successful transition from graduate school to new careers. ${ }^{45}$

As previously reported, more than half of the recent graduates experienced some form of mentoring during their MLIS graduate careers. Their experiences as mentees may bias their expectations that this type of relationship will also be available when they begin work in academic libraries. Hence, consideration must be given to the expectations of new librarians, as they are indicators of long-term retention and organizational success. ${ }^{46}$

When asked "Who do you think would be appropriate mentors in an academic library?" and given a choice of potential candidates (see table 8), all groups except university administration view library colleagues as the best potential mentors. University administrators seem to be noncommittal about recommending mentors. Generally, this reinforces the lack of support that mentoring programs receive by university administrators, further discussed in the mentoring support section below. It also supports

\begin{tabular}{|l|c|c|c|c|c|}
\hline \multicolumn{6}{|c|}{ TABLE 8 } \\
Who Do You Think Would be Appropriate Mentors in an Academic Library? \\
(Choose All That Apply)
\end{tabular}


the notion that academic librarians view mentoring as something that should not include your supervisor. When supervisors act as mentors, there is an inescapable tension between the roles of mentor and evaluator. ${ }^{47}$ It is interesting then that recent graduates and college administrators would view supervisors as appropriate mentors. College administrators think that, along with supervisors, they themselves would be appropriate mentors. This may be because all of the college administrators are from smaller institutions (less than 10,000), with smaller staff sizes (less than 20), which limits the possible pool of mentors. Adding themselves to the mentoring relationship then increases the potential mentors at their institution.

\section{Mentoring Activities}

Mentoring activities can be described on two levels: those activities that benefit the individual and their professional development, and those that benefit the organizational goals of the library. ${ }^{48}$ Although the important mentoring activities detailed in this research focus mainly on the individual and his or her professional development, the outcome, as outlined in the literature review, would directly benefit the organization.

All of the groups were surveyed to characterize their perceptions of what activities are important components of a mentoring relationship. Respondents were given a 5-point scale to rate the importance of each activity (1=not important; $2=$ somewhat important; $3=$ neutral; $4=$ important; $5=$ very important). If 70 percent or more of the respondents rated the activity as important or very important, then, for the purpose of this study, the activity was deemed to be a significant expectation in a mentoring relationship. Although this criterion is somewhat arbitrary, it serves the purpose of highlighting activities that the respondents supported.

The mentoring activities were divided into themes and adapted from library and nonlibrary literature. ${ }^{49}$ The five themes are career guidance, evaluation, academic expertise, psychosocial support, and role model. Open-ended responses ("I would also expect a mentor to...") aided in framing the mentoring activities, also providing an opportunity for respondents to add mentoring activities that had not been included by the researchers. Table 9 displays the percentage of respondents who indicated that an activity was either important or very important, grouped by mentoring themes.

\section{Activity 1: Evaluation}

"I do not view a mentor as an evaluator, but as a colleague who shares experiences and insights." (Administrator Group)

Formal evaluation, judgment, or documentation of the mentoring relationship is not strongly considered to be important by any of the respondent groups. Although, somewhat surprisingly, 69 percent of recent graduates and 61 percent of college librarians view performance evaluation as important or very important, only about one-third or less of university librarians and administrators believe that evaluation should play a role in a mentoring relationship. Thus, the groups are somewhat split on this role of a mentor. Reporting to supervisors receives quite weak support, with less than 50 percent of each group indicating that it was important or very important. In fact, university administrators were strongly against this potential component of a mentoring relationship, being the lowest to support it at 7 percent. Without record keeping or reporting mechanisms, mentees may feel they have the ability to share and learn without judgment. Oud found that new librarians were looking for support without judgment. ${ }^{50}$ In contrast, the present results for recent graduates might indicate that they believe that a mentor should be in a position to evaluate their performance. These findings are similar to those in table 8, where 92 percent of the recent graduates reported that their supervisors would be appropriate mentors. 


\begin{tabular}{|c|c|c|c|c|c|}
\hline \multicolumn{6}{|c|}{$\begin{array}{c}\text { TABLE } 9 \\
\text { Mentoring Activities }\end{array}$} \\
\hline $\begin{array}{l}\text { Mentoring } \\
\text { Activity }\end{array}$ & $\begin{array}{c}\text { Recent } \\
\text { MLIS Grads } \\
(\mathbf{n}=\mathbf{2 1})\end{array}$ & $\begin{array}{c}\text { College } \\
\text { Librarians } \\
(\mathrm{n}=43)\end{array}$ & $\begin{array}{l}\text { University } \\
\text { Librarians } \\
(\mathrm{n}=\mathbf{2 4 5})\end{array}$ & $\begin{array}{c}\text { College } \\
\text { Administrators } \\
(\mathbf{n}=7)\end{array}$ & $\begin{array}{c}\text { University } \\
\text { Administrators } \\
(\mathrm{n}=14)\end{array}$ \\
\hline \multicolumn{6}{|c|}{ Evaluation } \\
\hline $\begin{array}{l}\text { Evaluate } \\
\text { performance }\end{array}$ & $69 \%$ & $61 \%$ & $35 \%$ & $43 \%$ & $21 \%$ \\
\hline $\begin{array}{l}\text { Report to supervisor } \\
\text { about relationship }\end{array}$ & $43 \%$ & $45 \%$ & $15 \%$ & $28 \%$ & $7 \%$ \\
\hline \multicolumn{6}{|c|}{ Academic Expertise } \\
\hline $\begin{array}{l}\text { Advise on prepara- } \\
\text { tion of promotion } \\
\text { and tenure materials }\end{array}$ & $83 \%$ & $72 \%$ & $80 \%$ & $57 \%$ & $72 \%$ \\
\hline $\begin{array}{l}\text { Act as a research } \\
\text { resource }\end{array}$ & $61 \%$ & $65 \%$ & $50 \%$ & $58 \%$ & $50 \%$ \\
\hline $\begin{array}{l}\text { Assist with grant } \\
\text { writing }\end{array}$ & $43 \%$ & $42 \%$ & $35 \%$ & $14 \%$ & $36 \%$ \\
\hline \multicolumn{6}{|c|}{ Career Guidance } \\
\hline $\begin{array}{l}\text { Assist with } \\
\text { networking }\end{array}$ & $87 \%$ & $90 \%$ & $77 \%$ & $86 \%$ & $72 \%$ \\
\hline $\begin{array}{l}\text { Help with setting } \\
\text { professional goals }\end{array}$ & $83 \%$ & $88 \%$ & $78 \%$ & $86 \%$ & $57 \%$ \\
\hline Career counseling & $82 \%$ & $79 \%$ & $81 \%$ & $47 \%$ & $57 \%$ \\
\hline Offer challenges & $69 \%$ & $75 \%$ & $65 \%$ & $86 \%$ & $79 \%$ \\
\hline $\begin{array}{l}\text { Open doors for } \\
\text { opportunities }\end{array}$ & $56 \%$ & $81 \%$ & $65 \%$ & $43 \%$ & $64 \%$ \\
\hline \multicolumn{6}{|c|}{ Psychosocial Support } \\
\hline $\begin{array}{l}\text { Provide candid } \\
\text { feedback }\end{array}$ & $100 \%$ & $100 \%$ & $98 \%$ & $100 \%$ & $86 \%$ \\
\hline $\begin{array}{l}\text { Show interest and } \\
\text { listen to my profes- } \\
\text { sional concerns }\end{array}$ & $92 \%$ & $93 \%$ & $96 \%$ & $100 \%$ & $93 \%$ \\
\hline $\begin{array}{l}\text { Help with orientation } \\
\text { to library culture }\end{array}$ & $96 \%$ & $93 \%$ & $91 \%$ & $72 \%$ & $79 \%$ \\
\hline $\begin{array}{l}\text { Provide } \\
\text { encouragement }\end{array}$ & $96 \%$ & $95 \%$ & $90 \%$ & $86 \%$ & $64 \%$ \\
\hline Share library gossip & $13 \%$ & $5 \%$ & $10 \%$ & $0 \%$ & $0 \%$ \\
\hline \multicolumn{6}{|c|}{ Role Model } \\
\hline $\begin{array}{l}\text { Act as professional } \\
\text { role model }\end{array}$ & $96 \%$ & $100 \%$ & $94 \%$ & $86 \%$ & $93 \%$ \\
\hline $\begin{array}{l}\text { Confidential } \\
\text { communication }\end{array}$ & $87 \%$ & $98 \%$ & $93 \%$ & $86 \%$ & $93 \%$ \\
\hline $\begin{array}{l}\text { Share own profes- } \\
\text { sional experiences }\end{array}$ & $92 \%$ & $93 \%$ & $95 \%$ & $86 \%$ & $86 \%$ \\
\hline
\end{tabular}




\section{Activity 2: Academic Expertise}

"Academic librarianship is not straightforward and a lot is expected of you. Any time devoted to the explanation of publishing expectations, special projects, promotion and tenure, is very welcome. It's a complicated world and often new academic librarians are left to figure it out alone." (Administrator Group)

Academic expertise consists of the set of proficiencies that a mentor gains throughout his or her academic library career, including knowledge from other educational and employment experiences. Except for advice on promotion and tenure materials, where all but college administrators view it as important or very important, the other activities were not viewed as important. The other activities with low rates of importance are these: 1) act as a research resource and 2) assist with grant writing.

As outlined in the literature review, mentoring programs were developed for librarians to meet the research-related requirements to achieve tenure and promotion. ${ }^{51} \mathrm{It}$ is reassuring to see then that almost all of the respondents agree that mentoring can play a role in the promotion and tenure process.

The results are somewhat perplexing in regard to research and grant writing. These tasks are necessary elements for many academic librarians, and they may not be prepared. Although librarian education is oriented toward professional rather than research practice, many library workers in Canadian colleges and universities work in a unionized environment of faculty associations with academic or research responsibilities. Traditionally, librarians have not been responsible for conducting original research, but currently 75 percent of Canadian university librarians are part of a faculty association in which some type of academic activity may be required. ${ }^{52}$ Notably, responses for the current study indicate that 88 percent of college and 89 percent of university librarians work under a collective agreement, with 63 percent and 97 percent, respectively, as part of a faculty association. Although college collective agreements may not have a tenure requirement, it is becoming standard for university libraries. It is surprising then that mentoring activities about academic expertise did not receive extremely high levels of support for the university librarian and administration groups in particular. As for new graduates, they too should understand the important role of academic responsibilities for successful recruitment and assimilation into an academic library.

There are many possibilities to account for a perceived lack of importance for research and grant writing. It might be due to the naiveté of a new librarian not knowing that he or she needs help with research or grant writing. Alternatively, there could be others who know they need guidance but do not consider their library colleagues capable of providing that guidance. Regarding funding opportunities, librarians may not consider applying for funding due to the time involved in the application procedure, the low success rates, or a lack of need of research funds for their type of research. However, as a new culture emerges for research librarians, there may be a shift beginning with recent graduates. It is possible that reverse mentoring may surface, in which newer librarians mentor experienced librarians about academic responsibilities that were not previously part of their job or their training.

\section{Activity 3: Career Guidance}

"I would want my mentor to share professional experiences... and to help me reflect critically on my own goals, career choices, and practices." (Librarian Group)

Career Guidance includes the opportunities and support that the mentor provides for the mentee, through conversation, advice, and suggestions about their career. As seen in table 9, all respondents agree that assistance with networking is an important or very important activity. In fact, Culpepper refers to mentoring as the "ultimate in career training for many academic librarians. ${ }^{153}$ Career counseling, although important 
or very important for new graduates and librarians, is not seen as appropriate for administrators. Arnold found that mentors had a significant impact on career decisions of newer librarians. ${ }^{54}$ For administrators, advising on careers may be viewed as a conflict when the outcome of career counseling may not benefit the organization.

\section{Activity 4: Psychosocial Support}

"A mentor should be someone I can trust to be non-judgmental and supportive." (Recent MLIS Graduate Group)

Psychosocial support focuses on motivation and approval, which is constructive and nonjudgmental. The respondents viewed most of the psychosocial support elements as important or very important mentoring activities (see table 9). The activities viewed as important by all the respondent groups were: providing candid feedback, showing interest and listening to my professional concerns, and orienting to the library culture. Providing encouragement was not an important activity for the university administrator group. Perhaps the activity of providing encouragement was viewed as too personal for the university administrator group to support. In contrast, the same group viewed the activity show interest and listen to my professional concerns to be important. These activities being somewhat similar except for the "professional" provision, it is assumed that providing encouragement may be considered too familiar for administrators in their supervisory positions.

The overwhelming response to psychosocial activities is also reflected in Oud's survey of new librarians who respond positively to support that helped them adjust to their workplace. ${ }^{55}$ Eby and Lockwood also report psychosocial support as one of the most commonly stated benefits of a formal corporate mentoring program. ${ }^{56}$

Sharing library gossip is not seen as an important part of a mentoring relationship by any of the respondents. The researchers included this activity as an internal validity measure to ensure that the survey was answered in a critical manner.

\section{Activity 5: Role Model}

"A mentor should provide real wisdom and insight regarding organizational or professional culture." (Librarian Group)

As seen in table 9, all participants view role modeling as an important or very important part of successful mentoring. The role model theme allows the mentee to observe the mentor and learn from his or her actions, including observation of personal values at work and strategies used to address problems. Role modeling is an effective mentoring activity in many professions and is appropriate for new librarians, as well as for those looking for leadership or management training. ${ }^{57}$ For example, role ambiguity is a major concern for new librarians, and having a professional role model could help clarify these roles. ${ }^{58}$

These five mentoring themes demonstrate that librarians have a preference for the activities that make up a mentoring program. Career guidance, psychosocial support, and role model themes include activities that are important or very important to librarians, while evaluation and academic expertise do not. Interestingly, researchers have found that the biggest differences between formal and informal mentoring are that the mentees report more career-related and psychosocial mentoring in informal than formal experiences. ${ }^{59}$ Similarly, Young and Perrewé examined mentoring relationships for positive outcomes and found that most relevant mentoring expectations also involved career-related and social support behaviors. ${ }^{60}$

\section{Mentoring Support}

Mentoring is one of the most powerful methods by which an organization's future can be shaped ${ }^{61}$ 
Mentoring expectations and preferred activities may be moot unless library administrators are willing to provide some type of support or acknowledgment of mentoring programs. It is unclear why less than 30 percent of both college and university administrator respondents have formal or informal mentoring programs at their institutions (see figure 2) when all of the college administrators and half of the university administrators agreed that mentoring would play a role in succession planning. Yet, predominantly, these programs do not exist. For the administrators who acknowledged a mentoring program (33\%), the budget of the program was undefined, none, or a "time-only" cost. These results are consistent with Stevens and Streatfeild, who found that, in a group of new librarians, mentoring opportunities were important for retention, but mentoring support was negligible. ${ }^{62}$ Black and Leysen also reported that almost all administrators felt that mentoring librarians, in this case entry-level librarians, to be a beneficial experience, but also thought the programs were onerous. ${ }^{63}$

To develop an effective mentoring program, it is important to understand the potential drawbacks or risks perceived by administrators so these issues may be addressed. As seen in table 10, library administrators provide many reasons for the absence of a mentoring program that can be grouped by lack of opportunity, understanding, or resources.

In general, the issues administrators have with mentoring are similar to issues that mentors and mentees have expressed in qualitative investigations of formal mentoring programs and anecdotal experiences. ${ }^{64}$ The most common issues reported were mentor/mentee mismatch, mentor neglect, and communication problems in the mentoring relationship. Hence the reasons, drawbacks, and risks should be seriously considered for all participants and the organization when developing a mentoring program. For example, a lack of mentoring opportunities because of remote locations may succeed with virtual mentoring. ${ }^{65}$ The lack of resources and understanding must be balanced with research findings that highlight benefits of succession planning and restructuring that may result due to effective mentoring.

\begin{tabular}{|l} 
TABLE 10 \\
$\qquad \begin{array}{l}\text { Administrators: Absence of Mentoring Programs } \\
\text { (Reasons, Drawbacks and Risks) }\end{array}$ \\
\hline $\begin{array}{l}\text { Lack of Opportunity } \\
\text { Lack of turnover to necessitate mentoring. } \\
\text { Residing in a remote location translates into a lack of mentoring opportunities. }\end{array}$ \\
Lack of Resources \\
Lack of time as other priorities take precedent. \\
Mentoring is resource-intensive. \\
Lack of Understanding \\
When librarians asked about current "needs" at feedback session, mentoring not \\
mentioned. \\
Cannot agree on mentoring program details within the library system. \\
If it is an informal mentoring program, it may not be taken seriously. \\
It is problematic matching mentors with mentees. \\
Mentors may misguide mentees in unsuccessful directions. \\
It may be viewed as preferential treatment for those chosen to be mentors, who may \\
then be favoured for advancement. \\
Mentoring requires a well-defined program with goals and outcomes. \\
A formal mentoring program could run into Collective Agreement challenges.
\end{tabular}




\section{Limitations}

Four limitations of the present research are noteworthy. First, informal mentoring relies on individuals, not administration for the mentoring relationship and, as such, administrators' knowledge of this mentoring may be limited. Second, as mentioned previously, to maintain anonymity with survey responses, the researchers did not request the names of the institutions where the respondents work. Hence, findings are not mapped onto institutions, but individuals. Third, the MLIS recent graduates are from one institution's graduate program. Expanding the survey to other Canadian MLISgranting institutions may have changed mentoring expectations for this population sample. Finally, due to language limitations, all participants are from English academic libraries in Canada. Regardless of these limitations, this research highlights important characteristics of mentoring activities and expectations in Canadian academic libraries.

\section{Conclusions}

This research is the first to offer a Canadian perspective on mentoring in academic libraries that demonstrates the value of encouraging a mentoring culture to address recruitment, retention, and restructuring issues. Patterns that emerge include expected and preferred mentoring activities that can be used to motivate mentoring programs.

The current research is the first to include college and university librarians and administrators. Although there were minimal differential patterns between these two groups, it is important to acknowledge both academic settings. The obvious differences may be due to the small size of the colleges at which these librarians and administrators work.

Also unique to this study are the groups that are surveyed about mentoring expectations, activities, and support. The findings show that new graduates expect to be mentored, practicing librarians are available but not mentoring, and administration is at best hesitant about whether there should be mentoring programs at all. New MLIS graduates are driving the future of librarianship, and they expect mentoring to be available to them. Because academic library organizations want to recruit the most qualified candidates, offering a program that the candidates expect to be available is reasonable.

Along with the mentoring expectations of recent graduates, additional results characterize mentors in academic libraries. That is, librarians who were mentored as new librarians and librarians with more than ten years of experience in academic libraries have mentored others. Interestingly, the current demographics from this study portray many potential mentors. If administrators support the development of mentoring programs, the pattern of mentoring could be sustainable. Unfortunately, current programs are not supported, even though costs are negligible and all college administrators and half of the university administrators agree that some form of mentoring would aid in succession planning and restructuring in their libraries.

Previous research demonstrates that mentoring can play an important role through the career cycle of an academic librarian, and this work is no exception. Mentoring is often related to librarians at different career stages and needs to be recognized and examined within this context to be effective. ${ }^{66}$ Mentoring plays a role in recruiting and supporting new librarians, retaining current librarians with leadership and management, and encouraging the transfer of essential knowledge and skills for succession planning necessary for future library restructuring.

\section{Implications for LIS Education}

From the beginning of their graduate education, it is important that MLIS candidates learn about research expectations and what is required to succeed within an academic library setting. As Hicks states, "mentors can be invaluable in the life of a new profes- 
sional. MLIS programs teach new librarians the ins and outs of reference work, cataloguing, systems and even management basics. But they cannot prepare every student for every organizational culture that is out there." ${ }^{67}$ The LIS education component would include addressing the research responsibilities that may be required when working under a collective agreement. As new librarians apply for jobs, they need to comprehend the scope of these responsibilities. During job interviews, they need to inquire about types of mentoring that would be available to support their transition to a new environment.

\section{Implications for Practice in Academic Libraries}

As suggested in the 8 Rs study, a successful mentoring program may attract new librarians, retain current librarians, and aid in the succession planning facing many institutions as librarians retire and library budgets shrink. ${ }^{68}$ This investigation into mentoring in academic libraries has brought a common understanding of important mentoring activities for Canadian academic libraries. While no claim is being made that these mentoring activities are definitive, this research demonstrates that recent MLIS graduates, practicing librarians, and administrators in college and university libraries find it valuable to engage in, or support, mentoring programs developed around career guidance, psychosocial support, and role model activities. It is important to reevaluate how mentoring is framed and to include mentoring activities that are important to academic librarians from the start of their careers, through promotion and tenure processes, to support in a formal leadership role if desired. 


\section{Appendix A. Surveys for 1) Recent MLIS Graduates, 2) College and University Librarians, and 3) College and University Library Administrators}

\section{1) Recent MLIS Graduates}

1. I am a recent MLIS graduate. Yes / No

2. I am interested in working in an academic library. Yes / No

3. I have taken the following classes for my MLIS degree (please select all that apply):

$\square$ Academic Libraries

Instructional Strategies for Information Professionals

$\square$ Advanced Information Sources and Services

$\square$ Collection Development

$\square$ Legal Information Sources and Services

$\square$ Managing Vendor Relations

$\square$ Introduction to Collection Development Practices in Academic Libraries

$\square$ GIS in Academic Libraries

$\square$ Government Information

4. As a graduate student in the MLIS program, I participated in the following activities in an academic library (please select all that apply):

$\square$ Job shadowing

$\square$ Library association student mentoring

$\square$ Co-operative placement

$\square$ Other, please specify:

5. I am currently employed in an academic library as a professional librarian. Yes / No

6. I am currently employed as a ...

$\square$ full-time professional librarian

$\square$ part-time professional librarian

$\square$ contract / term professional librarian

$\square$ Other, please specify:

7. Thinking about my future employment in an academic library, I am expecting the following type of mentoring program to be available:

$\square$ Formal mentoring-organized by administration, I would be expected to participate

$\square$ Informal mentoring-I would independently seek someone out with more experience

$\square$ I do not expect any type of mentoring program to be available

$\square$ Other, please specify:

8. I think that the following people would be good mentors in my role as an academic librarian:

$\square$ my supervisor

$\square$ a library director

$\square$ the university librarian / dean

$\square$ faculty members within the institution

$\square$ a library colleague from the same department

$\square$ Other, please specify: 
9. I would expect a mentor to do the following (please rate the importance of each of these items): Very Important; Important; Neutral; Somewhat Important; Not at all Important; N/A

- $\quad$ provide career counseling

- keep our communications confidential

- act as a professional role model

- show interest and listen to me and listen to my professional concerns

- share library gossip

- open doors for opportunities

- $\quad$ provide encouragement

- offer challenges

- $\quad$ share their own professional experiences with me

- $\quad$ assist with grant writing

- $\quad$ provide knowledge of a discipline or subject area

- help with orientation to library culture

- $\quad$ advise on preparation of promotion and tenure materials

- $\quad$ evaluate my performance

- $\quad$ help with setting my professional goals

- $\quad$ provide candid feedback

- $\quad$ assist with networking

- report to supervisor on progress of our mentor / mentee relationship

- act as a research resource

I would also expect a mentor to (please describe):

10. I would expect these results from a mentoring relationship: Very Important; Important; Neutral; Somewhat Important; Not at all Important; N/A

- collaboration on a peer-reviewed publication

- collaboration on a conference presentation or poster

- more service opportunities (community, professional, university or college)

- $\quad$ exposure to new teaching methods / techniques

- $\quad$ support for job changes / promotions

- reduction of professional isolation

I would also expect the following from a mentoring relationship (please describe):

\section{Demographics}

1. Gender

$\square$ Male

$\square$ Female

2. Age group
口 20-25
口 26-30
31-40
41-50
51-60
口 61 and over

3. Additional degrees completed (please specify degree):

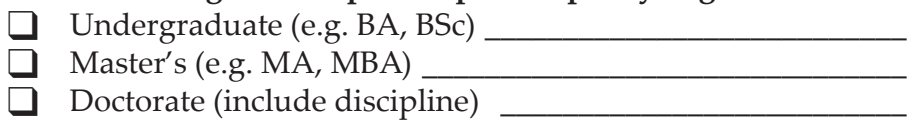




\section{2) College and University Academic Librarians}

1. What best describes the institution at which you work?

$\square$ College library

$\square$ University library

$\square$ Other, please specify:

2. How many students are enrolled at your institution?
$\square$ Less than 5,000
- 5,000 to 10,000
- 10,000 to 20,000
$\square$ Over 20,000

3. How many professional librarians are employed by your institution (including yourself, if appropriate)?

4. Does your institution have more than one library? Yes / No

5. If yes, how many libraries?

6. Does your institution have more than one campus? Yes / No

7. If yes, how many campuses?

8. Are the librarians at your institution covered by a collective agreement? Yes / No

9. If yes, what best describes the collective agreement:

$\square$ Faculty association

$\square$ Professional-Managerial

$\square$ Other, please specify:

10. What best describes your current employment status?

$\square$ full-time professional librarian

$\square$ part-time professional librarian

$\square$ contract / term professional librarian

$\square$ other (please describe):

11. Are you a mentor within your library or institution? Yes / No

12. What best describes the type of mentoring in which you participate?

$\square$ Formal mentoring-organized by administration / organization; assigned a mentee; expected to participate

$\square$ Informal mentoring-someone with less experience has sought you out or you have sought them

$\square$ Other, please specify:

$\square$ Please use the space below to include additional comments about being a mentor.

13. Are you a mentor to a librarian outside of your library or institution? Yes / No

14. What best describes the type of mentoring outside your library or institution in which you participate?

$\square$ Formal mentoring-organized by administration / organization; assigned a mentee; expected to participate

$\square$ Informal mentoring-someone with less experience has sought you out or you have sought them

$\square$ Other, please specify:

Please use the space below to include additional comments about being a mentor. 
15. Who do you think would be appropriate mentors in an academic library (choose all that apply):

$\square$ supervisors

$\square$ library directors

$\square$ university librarian / dean

$\square$ faculty members within the institution

$\square$ library colleagues from the same department

$\square$ other staff (please describe):

16. How important are the following items in a mentoring relationship (please rate the importance of each of these items)? Very Important; Important; Neutral; Somewhat Important; Not at all Important; N/A

- $\quad$ provide career counseling

- keep communications confidential

- act as a professional role model

- show interest and listen to professional concerns

- $\quad$ share library gossip

- open doors for opportunities

- provide encouragement

- offer challenges

- share professional experiences

- $\quad$ assist with grant writing

- $\quad$ provide knowledge of a discipline or subject area

- help with orientation to library culture

- $\quad$ advise on preparation of promotion and tenure materials

- evaluate performance

- help with setting professional goals

- provide candid feedback

- $\quad$ assist with networking

- report to supervisor on progress of mentor / mentee relationship

- $\quad$ act as a research resource

I would also expect a mentor to: (please describe):

17. When you began your career as a librarian, did you have a mentor? Yes / No

18. If you did not have a mentor, did you expect to have one? Yes / No

19. As a mentee, how important are the following items in a mentoring relationship? Very Important; Important; Neutral; Somewhat Important; Not at all Important; N/A

- collaboration on a peer-reviewed publication

- collaboration on a conference presentation or poster

- more service opportunities (community, professional, university or college)

- $\quad$ exposure to new teaching methods / techniques

- $\quad$ support for job changes / promotions

- reduction of professional isolation

20. Please describe additional expectations that you would have as a mentee in a mentoring relationship: 


\section{3) College and University Library Administrators}

1. What best describes the institution at which you work?

$\square$ College library

$\square$ University library

$\square$ Other, please specify:

2. How many students are enrolled at your institution?
$\square$ Less than 5,000
- 5,000 to 10,000
$\square 10,000$ to 20,000
$\square$ over 20,000

3. What is your title?
$\square$ University Librarian
$\square$ Dean of Libraries
$\square$ Director of Libraries
Associate University Librarian
$\square$ Chief Librarian
$\square$ Other, please specify:

4. How many professional librarians are employed by your institution (including yourself, if appropriate)?

5. Does your institution have more than one library? Yes / No

6. If yes, how many libraries?

7. Does your institution have more than one campus? Yes / No

8. If yes, how many campuses?

9. Are the librarians at your institution covered by a collective agreement? Yes / No

10. If yes, what best describes the collective agreement:

$\square$ Faculty association

$\square$ Professional-Managerial

$\square$ Other, please specify:

11. Does your library or institution have a mentoring program? Yes / No

12. What best describes your mentoring program?

$\square$ Formal mentoring - organized by administration, I am expected to participate

$\square$ Informal mentoring-independently seek mentoring or mentee opportunities

$\square$ Other (please describe):

13. Do you consider the mentoring program to be a success? Yes / No

14. What is the annual cost of your mentoring program?

15. Please provide details on why or why not your mentoring program is a success.

16. To the best of your knowledge, do the librarians within your institution actively participate in mentoring opportunities (within or outside of your library or institution)? as Mentors / as Mentees / unsure

17. From your perspective, are there any drawbacks or risks involved with having a mentoring program at your library or institution?

18. Would mentoring be advantageous in succession planning at your library or institution? Yes / No / Unsure, please specify: 
19. What are some of the reasons why you do not have a mentoring program (choose all that apply)?

$\square$ Lack of interest

$\square$ Cost prohibitive

$\square$ Too few people for effective mentoring program

$\square$ Other, please specify:

20. Are you a mentor within your library or institution? Yes / No

21. What best describes the type of mentoring in which you participate?

$\square$ Formal mentoring-organized by administration / organization; assigned a mentee; expected to participate

$\square$ Informal mentoring-someone with less experience has sought you out or you have sought them

$\square$ Other, please specify:

Please use the space below to include additional comments about being a mentor.

22. Are you a mentor to a librarian outside of your library or institution? Yes / No

23. What best describes the type of mentoring outside of your library or institution in which you participate?

$\square$ Formal mentoring - organized by administration / organization; assigned a mentee; expected to participate

$\square$ Informal mentoring-someone with less experience has sought you out or you have sought them

$\square$ Other, please specify:

Please use the space below to include additional comments about being a mentor.

24. Who do you think would be appropriate mentors in an academic library (choose all that apply):

$\square$ supervisors

$\square$ library directors

$\square$ university librarian / dean

$\square$ faculty members within the institution

$\square$ library colleagues from the same department

$\square$ other staff (please describe):

25. How important are the following items in a mentoring relationship? Very Important; Important; Neutral; Somewhat Important; Not at all Important; N/A

- provide career counseling

- $\quad$ keep communications confidential

- $\quad$ act as a professional role model

- show interest and listen to professional concerns

- $\quad$ share library gossip

- open doors for opportunities

- provide encouragement

- offer challenges 
- $\quad$ share professional experiences

- $\quad$ assist with grant writing

- $\quad$ provide knowledge of a discipline or subject area

- help with orientation to library culture

- $\quad$ advise on preparation of promotion and tenure materials

- evaluate performance

- help with setting professional goals

- provide candid feedback

- $\quad$ assist with networking

- report to supervisor on progress of mentor / mentee relationship

- act as a research resource

I would also expect a mentor to: (please describe):

26. When you began your career as a librarian, did you have a mentor? Yes / No 27. If you did not have a mentor, did you expect to have one? Yes / No

28. As a mentee, how important are the following items in a mentoring relationship? Very Important; Important; Neutral; Somewhat Important; Not at all Important; N/A

- collaboration on a peer-reviewed publication

- collaboration on a conference presentation or poster

- more service opportunities (community, professional, university or college)

- $\quad$ exposure to new teaching methods / techniques

- $\quad$ support for job changes / promotions

- reduction of professional isolation

Please describe additional expectations that you would have as a mentee in a mentoring relationship:

\section{Librarian and Administrator RESPONDENTS-Demographics}

1. In which province / territory do you currently work?

$\begin{array}{ll}\square & \text { Alberta } \\ \square & \text { British Columbia } \\ \square & \text { Manitoba } \\ \square & \text { New Brunswick } \\ \square & \text { Newfoundland and Labrador } \\ \square & \text { Northwest Territories } \\ \square & \text { Nova Scotia } \\ \square & \text { Nunavut } \\ \square & \text { Ontario } \\ \square & \text { Prince Edward Island } \\ \square & \text { Quebec } \\ \square & \text { Saskatchewan } \\ \square & \text { Yukon }\end{array}$

2. Gender

$\square$ Male

$\square$ Female

3. Age group
口 20-25
口 26-30 


$\begin{array}{ll}\square & 31-40 \\ \square & 41-50 \\ \square & 51-60 \\ \square & 61 \text { and over }\end{array}$

4. What degrees do you have?

\begin{tabular}{l}
$\square$ Undergraduate (e.g. BA, BSc) \\
$\square$ Master's (e.g. MA, MBA, MLIS) \\
$\square$ Doctorate (specify discipline) \\
\hline
\end{tabular}

5. How many years have you worked in an academic library?

$\square$
$\square$ to 5 years
6 to 10 years
11 to 20 years
$\square \quad$ more than 21 years

\section{Notes}

1. Jennifer Arnold, "The Community College Conundrum: Workforce Issues in Community College Libraries," Library Trends 59, no. 1 (2010): 220-36.

2. 8Rs Canadian Library Human Resource Study: The Future of Human Resources in Canadian Libraries (Edmonton, Alberta: 8Rs Canadian Library Human Resource Study, 2005).

3. Marilu Goodyear, "Mentoring: A Learning Collaboration," EDUCAUSE Quarterly 29, no. 4 (2006): 51-53.

4. Tammy Allen, Elizabeth Lentz, and Rachel Day, "Career Success Outcomes Associated with Mentoring Others," Journal of Career Development 32, no. 3 (2006): 272-85, doi:10.1177/0894845305282942; Tammy D. Allen, Lillian T. Eby, Mark L. Poteet, Elizabeth Lentz, and Lizzette Lima, "Career Benefits Associated with Mentoring for Proteges: A Meta-Analysis," Journal of Applied Psychology 89, no. 1 (2004): 127-36, dx.doi.org/10.1037/0021-9010.89.1.127.

5. Lillian T. Eby and Angie Lockwood, "Protégés' and Mentors' Reactions to Participating in Formal Mentoring Programs: A Qualitative Investigation," Journal of Vocational Behavior 67, no. 3 (2005): 441-58, dx.doi.org/10.1016/j.jvb.2004.08.002.

6. Allen, Lentz, and Day, "Career Success Outcomes Associated with Mentoring Others."

7. Eby and Lockwood, "Protégés' and Mentors' Reactions to Participating in Formal Mentoring Programs."

8. Stephanie C. Payne and Ann H. Huffman, "A Longitudinal Examination of the Influence of Mentoring on Organizational Commitment and Turnover," Academy of Management Journal 48, no. 1 (2005): $158-68$.

9. Angela M. Young and Pamela L. Perrewé, "The Role of Expectations in the Mentoring Exchange: An Analysis of Mentor and Protégé Expectations in Relation to Perceived Support," Journal of Managerial Issues 16, no. 1 (2004): 103-26.

10. Pamela Mathews, "Academic Mentoring: Enhancing the Use of Scarce Resources," Educational Management \& Administration 31, no. 3 (2003): 313-34, doi:10.1177/0263211X03031003007.

11. Jetta Carol Culpepper, "Mentoring Academic Librarians: The Ultimate in Career Guidance," College \& Undergraduate Libraries 7, no. 2 (2000): 71-81; Dana Keyse, Elizabeth W. Kraemer, and Julie Voelck, "Mentoring Untenured Librarians: All It Takes Is a Little Un-TLC," College $\mathcal{E}$ Research Libraries News 64 (June 2003): 378-80; Betty J. Turock, "Women and Leadership," Journal of Library Administration 32, no. 3/4 (2001): 111-37.

12. Janice J. Kirkland, “The Missing Women Library Directors: Deprivation Versus Mentoring," College \& Research Libraries 58, (July 1997): 375-83.

13. 8Rs Canadian Library Human Resource Study: The Future of Human Resources in Canadian Libraries

14. Bonnie A. Osif, "Successful Mentoring Programs: Examples from within and without the Academy," Journal of Business \& Finance Librarianship 13, no. 3 (2008): 335-47, doi:10.1080/08963560802183096.

15. Ellen I. Shupe and Stephanie K. Pung, “Understanding the Changing Role of Academic 
Librarians from a Psychological Perspective: A Literature Review," Journal of Academic Librarianship 37, no. 5 (2011): 409-15, doi:10.1016/j.acalib.2011.06.005.

16. Culpepper, "Mentoring Academic Librarians."

17. Eileen K. Bosch, Hema Ramachandran, Susan Luévano, and Eileen Wakiji, “The Resource Team Model: An Innovative Mentoring Program for Academic Librarians," New Review of Academic Librarianship 16, no. 1 (2010): 57-74; Ann Manning Fiegen, "Mentoring and Academic Librarians: Personally Designed for Results," College \& Undergraduate Libraries 9, no. 1 (2002): 23-32; Nikhat Ghouse and Jennifer Church-Duran, "And Mentoring for All: The KU Libraries' Experience," Portal: Libraries and the Academy 8, no. 4 (2008): 373-86; Margaret Law, "Mentoring Programs: In Search of the Perfect Model," Feliciter 47, no. 3 (2001): 146-48;

18. Ashley E. Bonnette, "Mentoring Minority Librarians up the Career Ladder," Library Administration \& Management 18, no. 3 (2004): 134-39; Antonia Olivas and Richard Ma, "Increasing Retention Rates in Minority Librarians through Mentoring," Electronic Journal of Academic and Special Librarianship 10, no. 3 (2009), available online at http://southernlibrarianship.icaap.org/ content/v10n03/olivas_a01.html [accessed 2 March 2013].

19. Olivas and Ma, "Increasing Retention Rates in Minority Librarians through Mentoring."

20. Association of College and Research Libraries, Ad Hoc Task Force on Recruitment \& Retention Issues, Recruitment, Retention, and Restructuring: Human Resources in Academic Libraries: A White Paper (Chicago, Ill.: Association of College and Research Libraries, 2002).

21. William K. Black and Joan M. Leysen, "Fostering Success," Journal of Library Administration 36, no. 4 (2002): 3-27, doi:10.1300/J111v36n04_02.

22. Joanne Oud, "Adjusting to the Workplace: Transitions Faced by New Academic Librarians," College \& Research Libraries 69 (May 2008): 252-66.

23. Diana Farmer, Marcia Stockham, and Alice Trussell, "Revitalizing a Mentoring Program for Academic Librarians," College \& Research Libraries 70 (Jan. 2009): 8.

24. Heather Clark, William Nelson, Lisa Hoops-Parish, Marla Peppers, Deb Raftus, and Nedelina Tchangalova, "A Synthesis of Information from Current Resources on the Educational Needs of New Librarians," from ALA Emerging Leaders Program (2007), available online at http://drum. lib.umd.edu/bitstream/1903/7560/3/Literature\%20review_synthesis.pdf [accessed 2 March 2013].

25. Jen Stevens and Rosemary Streatfeild, "Recruitment and Retention," SPEC Kit 276 (Washington, D.C.: Association of Research Libraries, Office of Leadership and Management Services, 2006).

26. Molly Strothmann and Lila Angie Ohler, "Retaining Academic Librarians: By Chance or by Design?" Library Management 32, no. 3 (2011): 191-208, doi:10.1108/01435121111112907.

27. Lois Kuyper-Rushing, "A Formal Mentoring Program in a University Library: Components of a Successful Experiment," Journal of Academic Librarianship 27, no. 6 (2001): 440-46.

28. Keyse, Kraemer, and Voelck, "Mentoring Untenured Librarians."

29. Bosch, Ramachandran, Luévano, and Wakiji, "The Resource Team Model."

30. Judith M. Nixon, "Growing Your Own Leaders: Succession Planning in Libraries," Journal of Business \& Finance Librarianship 13, no. 3 (2008): 249-60, doi:10.1080/08963560802183229.

31. Jennifer Arnold, Lisa T. Nickel, and Lisa Williams, "Creating the Next Generation of Library Leaders," New Library World 109, no. 9/10 (2008): 444-56, doi:10.1108/03074800810910478.

32. Michael P. Rooney, "The Current State of Middle Management Preparation, Training, and Development in Academic Libraries," Journal of Academic Librarianship 36, no. 5 (2010): 383-93, doi:10.1016/j.acalib.2010.06.002.

33. Deborah Hicks, "The Practice of Mentoring: Reflecting on the Critical Aspects for Leadership Development," Australian Library Journal 60, no. 1 (2011): 66-74.

34. Deborah Hicks, "Negotiating Employer-Employee Relationships for New Professionals," Feliciter 54, no. 5 (2008): 207-09; Deborah Hicks, Jeannette Buckingham, and Margaret Law, "Mentoring and Supervision? Or, Mentoring Versus Supervision?" in Recruitment, Development, and Retention of Information Professionals: Trends in Human Resources and Knowledge Management, eds. Elisabeth Pankl, Danielle Theiss-White, Mary C. Bushing (Hershey, Pa.: Business Science Reference, 2010), 251-66.

35. Oud, "Adjusting to the Workplace."

36. Bonnette, "Mentoring Minority Librarians up the Career Ladder."

37. Claire Dygert and Markel Tumlin, "Tools for Tenure Trailblazing: Planning Productive Paths for Green Serialists," Report of a Program at the 2003 NASIG Conference 46, no. 3 (2004): 253-56, doi:10.1300/J123v46n03_09.

38. Osif, "Successful Mentoring Programs"; Bosch, Ramachandran, Luévano, and Wakiji, "The Resource Team Model"; Kuyper-Rushing, "A Formal Mentoring Program in a University Library"; Gail Munde, "Beyond Mentoring: Toward the Rejuvenation of Academic Libraries," Journal of Academic Librarianship 26, no. 3 (2000): 171-75.

39. Ann Ritchie and Paul Genoni, "Group Mentoring and Professionalism: A Programme 
Evaluation: Australian Library and Information Association Project," Library Management 23, no. 1/2 (2002): 68-78.

40. Law, "Mentoring Programs."

41. 8Rs Canadian Library Human Resource Study: The Future of Human Resources in Canadian Libraries.

42. Paulo Lopes Henriques and Carla Curado, "Pushing the Boundaries on Mentoring: Can Mentoring Be a Knowledge Tool?" Journal of Business Economics and Management 10, no. 1 (2009): 85-97, doi:10.3846/1611-1699.2009.10.85-97.

43. Strothmann and Ohler, "Retaining Academic Librarians: By Chance or by Design?"

44. Olivas and Ma, "Increasing Retention Rates in Minority Librarians Through Mentoring."

45. Hicks, "Negotiating Employer-Employee Relationships for New Professionals"; Association of College and Research Libraries, Ad Hoc Task Force on Recruitment \& Retention Issues, Recruitment, Retention, and Restructuring: Human Resources in Academic Libraries: A White Paper.

46. Black and Leysen, "Fostering Success."

47. W. Brad Johnson, "Transformational Supervision: When Supervisors Mentor," Professional Psychology: Research and Practice 38, no. 3 (2007): 259-67, doi:10.1037/0735-7028.38.3.259.

48. Shin Freedman, "Effective Mentoring," IFLA Journal 35, no. 2 (2009): 171-82.

49. Goodyear, "Mentoring: A Learning Collaboration"; Eby and Lockwood, "Protégés' and Mentors' Reactions to Participating in Formal Mentoring Programs"; Culpepper, "Mentoring Academic Librarians"; Shupe and Pung, "Understanding the Changing Role of Academic Librarians"; Johnson, "Transformational Supervision"; Kathy E. Kram, Mentoring at Work: Developmental Relationships in Organizational Life, Organizational Behavior and Psychology Series (Glenview, Ill.: Scott Foresman, 1985).

50. Oud, "Adjusting to the Workplace."

51. Keyse, Kraemer, and Voelck, "Mentoring Untenured Librarians"; Kuyper-Rushing, "A Formal Mentoring Program in a University Library"; Dygert and Tumlin, "Tools for Tenure Trailblazing"; Vincent J. Novara, Phillip Brown, and M. Jane Williams, "Mentoring When Librarians Have Faculty Status," in Recruitment, Development, and Retention of Information Professionals: Trends in Human Resources and Knowledge Management, eds. Elisabeth Pankl, Danielle Theiss-White, Mary C. Bushing (Hershey, Pa: Business Science Reference, 2010), 267-80.

52. Justine Wheeler, "Academic Librarians as Leaders in Faculty Associations," in In Solidarity: Academic Librarian Union Activism and Participation in Canada, eds. Mary Kandiuk and Jennifer Dekker (Los Angeles, Calif.: Library Juice Press, forthcoming).

53. Culpepper, "Mentoring Academic Librarians."

54. Arnold, Nickel, and Williams, "Creating the Next Generation of Library Leaders."

55. Oud, "Adjusting to the Workplace."

56. Eby and Lockwood, "Protégés' and Mentors' Reactions to Participating in Formal Mentoring Programs."

57. Payne and Huffman, "A Longitudinal Examination of the Influence of Mentoring on Organizational Commitment and Turnover."

58. Shupe and Pung, "Understanding the Changing Role of Academic Librarians."

59. Georgia T. Chao, Pat M. Walz, and Philip D. Gardner, "Formal and Informal Mentorships: A Comparison on Mentoring Functions and Contrast with Nonmentored Counterparts," Personnel Psychology 45, no. 3 (1992): 619-36; Ellen A. Fagenson-Eland, Michelle A. Marks, and Karen L. Amendola, "Perceptions of Mentoring Relationships," Journal of Vocational Behavior 51, no. 1 (1997): 29-42, doi:10.1006/jvbe.1997.1592.

60. Young and Perrewé, "The Role of Expectations in the Mentoring Exchange."

61. Robert D. Stueart and Maureen Sullivan, Developing Library Leaders: A How-to-Do-It Manual ${ }^{\circledR}$ for Coaching, Team Building, and Mentoring Library Staff, Number 172 (New York: Neal-Schuman Pub., 2010), 71.

62. Stevens and Streatfeild, "Recruitment and Retention."

63. Black and Leysen, "Fostering Success."

64. Eby and Lockwood, "Protégés' and Mentors' Reactions to Participating in Formal Mentoring Programs"; Freedman, "Effective Mentoring"

65. Jonathan D. Eldredge, "Virtual Peer Mentoring (VPM) May Facilitate the Entire EBLIP Process," Evidence Based Library and Information Practice 5, no. 1 (2010): 7-16.

66. Freedman, "Effective Mentoring."

67. Hicks, "Negotiating Employer-Employee Relationships for New Professionals."

68. 8Rs Canadian Library Human Resource Study: The Future of Human Resources in Canadian Libraries. 